\title{
Validitas dan Praktikalitas Modul Reaksi Oksidasi Reduksi Berbasis Inkuiri Terbimbing Dilengkapi Soal High Order Thinking Skill (HOTS) untuk Siswa Kelas X SMA/MA
}

\section{The Validity and Practicality of Redox Reaction's Module Based on Guided Inquiry with High Order Thinking Skill's Question (HOTS) for $10^{\text {th }}$ Grade Students}

\author{
Y R Bahri ${ }^{1^{*}}$ and Iryani ${ }^{1}$ \\ 1 Pendidikan Kimia, Universitas Negeri Padang, Jl. Prof. Dr. Hamka, Air Tawar Barat, \\ Padang Utara, Sumatera Barat, Indonesia 25171 \\ *yvonnebahri33@gmail.com
}

ARTICLE INFO

Received 02 January 2020

Revised 23 January 2020

Published 18 May 2020

\begin{abstract}
This research aims to determine the category of validity and practicality of module based on guided inquiry on redox reaction with high order thinking skill's question (HOTS) for 10th grade students. This research uses a research design of the Plomp model development which consist of 3 phases: preliminary research, prototyping phase, assessment phase. The data were analysed using kappa moment. This module is validated by 5 validators that consisting of 3 chemistry lecture and 2 chemistry teacher who are experienced and experts in their fields. The result of this research showed that the module had a high category of validity with a kappa moment of 0,77. The module has a high category of practicality based on the teacher's questionnaire responses which has a kappa moment of 0.80 and the module practicality category based on student questionnaires is equal to 0.70.
\end{abstract}

\section{KEYWORDS}

Guided Inquiry, HOTS, Module, Plomp, Redox Reaction

\begin{abstract}
ABSTRAK
Penelitian ini bertujuan untuk menentukan kategori validitas dan praktikalitas modul berbasis inkuiri terbimbing pada materi reaksi oksidasi reduksi yang dilengkapi soal tipe HOTS untuk siswa kelas X SMA/MA. Model pengembangan yang diterapkan dalam penelitian ini adalah model Plomp yang terdiri dari 3 tahapan yaitu penelitian awal, fase pengembangan prototipe, dan fase penilaian. Data yang diperoleh kemudian dianalisis dengan menggunakan momen kappa (k). Modul yang dikembangkan dinilai oleh 5 orang validator yang terdiri dari 2 orang guru kimia dan 3 orang dosen kimia yang telah berpengalaman dan ahli dibidangnya. Berdasarkan penelitian yang telah dilakukan didapatkan hasil bahwa modul yang dikembangkan mempunyai kategori kevalidan yang tinggi dengan momen kappa sebesar 0,77. Modul yang dikembangkan memiliki kategori kepraktisan yang tinggi berdasarkan angket praktikalitas respon guru dan peserta didik dengan masing-masing nilai momen kappa sebesar 0,80 dan 0,70.
\end{abstract}

KATA KUNCI

HOTS, Inkuiri Terbimbing, Modul, Plomp, Reaksi Oksidasi Reduksi 


\section{PENDAHULUAN}

Kurikulum 2013 revisi 2018 didesain untuk meningkatkan kemampuan peserta didik dari sisi sikap, pengetahuan, dan keterampilan secara utuh. Kurikulum 2013 revisi 2018 menganut pandangan dasar bahwa pembelajaran bukan hanya proses transfer ilmu pengetahuan dari guru ke peserta didik, melainkan peserta didik diharuskan untuk aktif dalam mencari, memproses, dan membangun pengetahuan dalam proses pembelajaran ${ }^{[1]}$.

Materi reaksi oksidasi reduksi adalah materi pokok yang dipelajari pada semester genap kelas $\mathrm{X}$. Berdasarkan observasi yang dilakukan di SMA Adabiah dan SMAN 1 Gunung Talang, sebagian besar peserta didik menilai materi reaksi redoks adalah materi yang sulit. Berdasarkan penelitian yang telah dilakukan oleh Pinta Medina (2015) dengan judul "Analisis Miskonsepsi Siswa Kelas X pada Materi Larutan Elektrolit dan Non-elektrolit serta Reaksi Oksidasi dan Reduksi di SMA Kota Padang” diperoleh bahwa miskonsepsi peserta didik pada materi reaksi redoks terjadi hampir pada seluruh materi tersebut. Dari penelitian ini disimpulkan bahwa konsep pada materi reaksi redoks bersifat abstrak dan sulit dipahami ${ }^{[2]}$.

Penelitian lain yang dilakukan oleh Riza Raudatul Jannah dan Lisa Utami (2017) didapatkan bahwa rerata peserta didik mengalami miskonsepsi dalam menentukan pengertian reaksi oksidasi reduksi karena banyaknya peserta didik yang masih ragu dalam menentukan pengertian reaksi oksidasi dan reduksi berdasarkan pelepasan dan penerimaan elektron. Selain pengertian oksidasi, peserta didik juga mengalami miskonsepsi dalam menentukan aturan bilangan oksidasi serta konsep oksidator dan reduktor ${ }^{[3]}$.

Meningkatkan keterampilan peserta didik dalam mengkonstruksi konsep dapat dilakukan melalui bantuan bahan ajar yang tepat. Bahan ajar yang tepat disusun dengan mengutamakan proses di samping fakta dan penguasaan konsep, mampu memberikan contoh aplikasi konsep di lingkungan sekitar peserta didik, baik melalui gambaran-gambaran makroskopis atau pun dengan simboliknya ${ }^{[4]}$.

Dalam proses pembelajaran peserta didik dituntut untuk mampu berpikir kritis. Oleh karena itu, pembelajaran dilakukan dengan menggunakan bahan ajar berupa modul yang dilengkapi informasi/ model berupa gambar, rumus, tabel data, atau grafik. Modul merupakan bahan ajar yang disusun secara terstruktur sehingga pemakainya mampu belajar dengan atau tanpa bimbingan seorang guru/fasilitator. Penggunaan modul dalam proses pembelajaran mampu merangsang situasi belajar yang lebih mengaktifkan peserta didik untuk menyelesaikan masalah-masalah di bawah pengawasan dan bimbingan guru ${ }^{[5]}$. Salah satu model pembelajaran yang dapat diterapkan guru untuk memaksimalkan penggunaan modul adalah model pembelajaran inkuiri terbimbing.
Inkuiri terbimbing merupakan suatu model karena menyediakan metodologi dan struktur tentang cara belajar dan hasil yang diinginkan. Model pembelajaran inkuiri terbimbing terfokus kepada aktivitas peserta didik untuk mencari dan menemukan jawaban dari suatu masalah ${ }^{[6]}$. Inkuiri terbimbing dinilai sebagai model pembelajaran yang mampu meningkatkan kemampuan kognitif peserta didik lebih baik daripada model pembelajaran konvensional[ ${ }^{[7]}$.

Tahapan model pembelajaran inkuiri terbimbing merupakan tahapan yang dapat membantu mengasah kemampuan berpikir tingkat tinggi peserta didik. Kemampuan berpikir tingkat tinggi atau High Order Thinking Skills (HOTS) merupakan kegiatan berpikir pada level satu tingkat lebih tinggi daripada menghafal. Kemampuan berpikir tingkat tinggi merupakan kemampuan untuk memanfaatkan pengetahuan serta pengalaman yang telah dimiliki untuk berpikir kritis dan kreatif dalam mengambil keputusan dan menyelesaikan masalah pada situasi baru ${ }^{[8]}$. Pemberian soal evaluasi bertipe HOTS dapat membantu mengukur kemampuan berpikir tingkat tinggi peserta didik ${ }^{[0]}$.

Penelitian pengembangan dan pengaruh penggunaan modul berbasis inkuiri terbimbing telah dilakukan oleh para peneliti sebelumnya, diantaranya penelitian yang dilakukan oleh Silvia Enmi Perifta (2018). Dari penelitian tersebut dapat disimpulkan bahwa modul hukum dasar kimia dan stoikiometri berbasis inkuiri terbimbing yang dihasilkan dengan menggunakan model pengembangan Plomp memiliki tingkat kevalidan sangat tinggi dengan nilai momen kappa (k) $0,81^{[10]}$.

Berdasarkan wawancara dan pembagian angket kepada peserta didik yang telah dilakukan di SMA Adabiah Padang dan SMAN 1 Gunung Talang diperoleh bahwa kedua SMA tersebut telah menggunakan kurikulum 2013. Bahan ajar yang digunakan adalah buku paket dan LKS/LKPD yang tampilannya dinilai kurang menarik oleh peserta didik. Bahan ajar yang digunakan dinilai masih belum mampu mengukur kemampuan berpikir tingkat tinggi peserta didik karena belum dilengkapi dengan soal-soal tipe HOTS, serta penyajiannya belum mencakup tiga level representasi kimia.

Berdasarkan uraian di atas, penulis telah melakukan penelitian untuk menguji bahan ajar yang telah dikembangkan dalam bentuk modul pembelajaran berbasis inkuiri terbimbing pada materi reaksi oksidasi reduksi dengan judul "Validitas Modul Reaksi Oksidasi Reduksi Berbasis Inkuiri Terbimbing untuk Siswa Kelas X SMA/MA".

\section{METODE}

\subsection{Prosedur Penelitian}

Penelitian ini dilakukan di SMA Adabiah Padang. Model penelitian yang digunakan dalam penelitian ini adalah model Plomp yang terdiri dari tiga tahapan yaitu tahapan investigasi awal (preliminary research), tahapan pembentukan 
prototipe (prototyping phase), dan tahapan penilaian

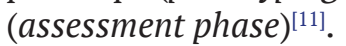

1. Tahap investigasi awal (preliminary research)

Tahap investigasi awal merupakan tahapan untuk melakukan analisis kebutuhan, analisis konteks (isi), studi literatur dan pengembangan kerangka konseptual.

2. Tahap pembentukan prototipe (prototyping phase)

Pembentukan prototipe ini terdiri dari beberapa fase atau tahapan dan untuk menyempurnakan prototipe yang dihasilkan dilakukan penilaian dengan evaluasi formatif melalui penelitian skala kecil (micro cycle of research). Pada tahapan pembentukan prototipe produk yang dibuat akan di uji coba dan direvisi berdasarkan evaluasi formatif.

3. Tahap penilaian (assessment phase)

Pada tahap ini dilakukan penilaian berupa evaluasi (semi-) sumatif dilakukan pada tahap ini untuk menyimpulkan apakah prototipe yang dibuat sudah memenuhi spesifikasi yang telah ditentukan sebelumnya.

\subsection{Teknik Analisis Data}

Teknik analisis lembar validitas dan praktikalitas dirujuk kepada categorical judgment yang dimodifikasi dari Boslaugh ${ }^{[12]}$. Pada categorical judgment, validator memberikan nilai pada masingmasing pernyataan tersebut. Nilai yang diperoleh dianalisis dengan formula Kappa Cohen, dimana pada akhir pengolahan diperoleh momen kappa.

$$
\text { momen kappa }(k)=\frac{\rho_{0}-\rho_{e}}{1-\rho_{e}}
$$

$k=$ nilai momen kappa

$\rho_{0}=$ proporsi yang tidak terealisasi

$\rho_{e}=$ proporsi yang terealisasi

Informasi mengenai category judgment dapat dilihat pada Tabel 1 .

Tabel 1. Kategori keputusan berdasarkan momen kappa $(k)$.

\begin{tabular}{c|c} 
Interval & Kategori \\
\hline $0,81-1,00$ & Sangat Tinggi \\
\hline $0,61-0,80$ & Tinggi \\
\hline $0,41-0,60$ & Sedang \\
\hline $0,21-0,40$ & Cukup \\
\hline $0,01-0,20$ & Rendah \\
\hline$\leqslant 0,00$ & Sangat Rendah
\end{tabular}

\section{HASIL DAN DISKUSI}

\subsection{Hasil}

\subsubsection{Penelitian awal (preliminary research)}

Tahap-tahap dalam investigasi awal diuraikan sebagai berikut.

\subsubsection{Analisis kebutuhan}

Hasil observasi yang dilakukan di SMA Adabiah Padang dan SMAN 1 Gunung Talang Solok menunjukkan bahwa bahan ajar yang digunakan di sekolah adalah buku paket dan LKS/LKPD yang tampilannya dinilai kurang menarik oleh peserta didik. Bahan ajar tersebut dinilai masih belum mampu mengukur kemampuan berpikir tingkat tinggi peserta didik karena belum dilengkapi dengan soal-soal tipe HOTS, serta penyajiannya belum mencakup tiga level representasi kimia.

\subsubsection{Analis konteks}

Materi yang dipilih pada pengembangan modul ini adalah materi reaksi oksidasi reduksi yang dipelajari pada semester genap kelas X. Kompetensi Dasar (KD) yang harus dicapai pada materi ini adalah:

3.9. Mengidentifikasi reaksi reduksi dan oksidasi menggunakan konsep bilangan oksidasi unsur.

4.9. Menganalisis beberapa reaksi berdasarkan perubahan bilangan oksidasi yang diperoleh dari data hasil percobaan dan atau melalui percobaan.

Langkah selanjutnya adalah merinci submateri reaksi redoks, yaitu menentukan submateri yang menuntut adanya percobaan langsung (aktivitas laboratorium) dan submateri yang hanya menuntut pembelajaran di dalam kelas (aktivitas kelas).

\subsubsection{Studi Literatur}

Hasil yang diperoleh berdasarkan studi literatur adalah sebagai berikut.

1. Bagian-bagian pada modul dirujuk dari komponen modul menurut Suryobroto (1983)

2. Referensi untuk materi reaksi oksidasi reduksi pada modul berasal dari buku-buku kimia universitas dan buku kimia SMA

3. Referensi untuk model pembelajaran inkuiri terbimbing dan keterampilan berpikir tingkat tinggi peserta didik adalah jurnal dan buku.

\subsubsection{Pengembangan Kerangka Konseptual}

Konsep-konsep penting yang harus dikuasai peserta didik dalam mempelajari materi reaksi redoks adalah reaksi oksidasi reduksi berdasarkan pelepasan dan pengikatan oksigen, reaksi oksidasi reduksi berdasarkan pelepasan dan penerimaan elektron, reaksi oksidasi reduksi berdasarkan perubahan bilangan oksidasi, penentuan bilangan oksidasi, oksidator dan reduktor serta reaksi autoredoks.

\subsubsection{Tahap pembentukan prototipe (prototyping phase)}

\subsubsection{Prototipe I}

Perancangan prototipe I yang dihasilkan menggunakan Publisher 2007. Jenis tulisan yang digunakan bervariasi dengan ukuran yang disesuaikan, diantaranya adalah Times New Roman dan Calibri serta Century Schoolbook pada bagian header. 
Kegiatan pembelajaran dirancang dengan menggunakan siklus belajar inkuiri terbimbing yaitu orientation, exploration, concept formation, application, dan closure. Pada tahap orientasi, peserta didik dipersiapkan untuk belajar. Tahap orientasi berisikan tujuan pembelajaran, motivasi, dan materi pendukung. Tahap eksplorasi dan pembentukan konsep merupakan tahapan peserta didik melakukan pengamatan melalui eksperimen dan mengeksplorasi model yang disajikan serta menjawab pertanyaan kunci yang mana pertanyaanpertanyaan tersebut dimaksudkan untuk membantu peserta didik untuk menemukan konsep.

Pada tahap aplikasi, peserta didik menerapkan konsep yang telah ditemukan ke dalam situasi yang baru. Beberapa soal latihan yang dibuat adalah soal dengan ranah kognitif $\mathrm{C} 4$ atau aspek analisis pada taksonomi Bloom revisi yang berguna untuk melatih keterampilan berpikir tingkat tinggi peserta didik. Pada tahap ini indikator berpikir tingkat tinggi yang dilatih yaitu menerapkan konsep dan prinsip/rumus yang telah diperoleh, dan menjawab pertanyaan pada soal-soal latihan.

Tahap penutup merupakan tahapan dimana peserta didik membuat kesimpulan mengenai konsep yang telah ditemukannya. Pada tahap ini indikator keterampilan berpikir kritis yang dilatih yaitu menarik kesimpulan berdasarkan hasil penyelidikan.

\subsubsection{Prototipe II}

Prototipe I yang telah dikembangkan diuji dengan evaluasi diri sendiri (self evaluation). Evaluasi diri sendiri dilakukan dengan menggunakan daftar cek (checklist) dari karakteristik atau spesifikasi desain. Hasil evaluasi diri sendiri terhadap prototipe I menunjukkan bahwa modul yang dikembangkan telah sesuai dengan tahapan inkuiri terbimbing baik untuk aktivitas kelas maupun aktivitas laboratoriumnya, namun komponen penyusun modul masih kurang lengkap di bagian lembar kunci jawaban soal evaluasi dan kepustakaan. Oleh karena itu, dilakukan revisi sehingga dihasilkan prototipe II.

\subsubsection{Prototipe III}

Selanjutnya prototipe II divalidasi oleh 2 orang guru kimia SMA Adabiah Padang dan 3 orang dosen kimia Universitas Negeri Padang. Ada pun informasi hasil analisis data validitas disajikan pada Gambar 1.

Validator memberikan saran-saran perbaikan berupa penyesuaian desain cover modul, permodelan, dan materi.

Setelah modul divalidasi kemudian dilakukan uji satu-satu. Dari hasil evaluasi satu-satu didapatkan bahwa modul berbasis inkuiri terbimbing yang dikembangkan sudah dapat membantu peserta didik untuk memahami materi reaksi oksidasi reduksi, memiliki desain gambar dan penampilan warna yang menarik. Namun penggunaan bahasa pada pertanyaan kunci perlu diperbaiki karena masih kurang bisa dipahami oleh peserta didik.
Hasil evaluasi satu-satu dan saran validator pada tahap validasi digunakan untuk revisi modul yang dikembangkan sehingga diperoleh prototipe III.

\section{Rerata Momen Kappa (k) Validitas oleh Validator}

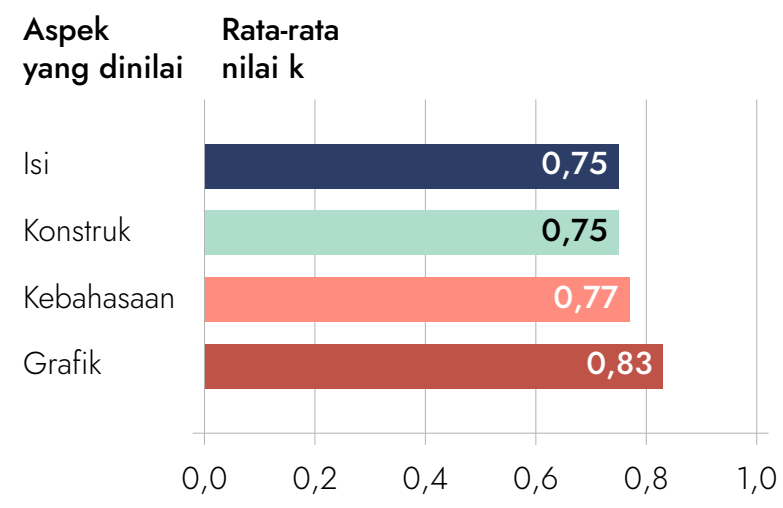

Gambar 1. Grafik rerata momen kappa (k) validitas modul oleh validator.

\subsubsection{Prototipe IV}

Pada tahap ini dilakukan evaluasi formatif berupa uji coba kelompok kecil (small group evaluation) terhadap prototipe III yang telah dihasilkan. Uji coba kelompok kecil bertujuan untuk melihat kepraktisan modul (prototipe III) yang ditujukan pada 1 kelompok kecil yang terdiri dari 6 orang peserta didik.

Hasil analisis evaluasi kelompok kecil dapat dilihat pada Tabel 2.

Tabel 2. Rerata momen kappa (k) small group evaluation.

\begin{tabular}{c|c|c} 
No & Aspek yang Dinilai & $\mathbf{k}$ \\
\hline 1 & Kemudahan penggunaan & 0,74 \\
\hline 2 & Efisiensi waktu pembelajaran & 0,68 \\
\hline 3 & Manfaat & 0,67 \\
\hline \multicolumn{2}{c}{ Rerata momen kappa } & $\mathbf{0 , 7 0}$
\end{tabular}

Hasil evaluasi small group pada Tabel 2 menunjukkan modul sudah memiliki tingkat praktikalitas yang tinggi, namun masih perlu dilakukan perbaikan khususnya pada bagian bahasa pertanyaan kunci pada modul. Oleh karena itu, modul direvisi sehingga terbentuk prototipe IV yang akan diujicobakan di lapangan (field test).

\subsubsection{Tahap penilaian (assessment phase)}

Hasil pengolahan data lembar penilaian angket respon guru dan peserta didik terdapat pada Tabel 3 dan Tabel 4.

Berdasarkan hasil analisis angket praktikalitas guru dan peserta didik yang memiliki 3 aspek penilaian didapatkan rerata momen kappa untuk praktikalitas modul berdasarkan angket respon guru sebesar 0,80 dan rerata momen kappa untuk praktikalitas modul berdasarkan angket respon peserta didik sebesar 0,77 sehingga dapat 
disimpulkan bahwa tingkat praktikalitas modul memiliki kategori kevalidan yang tinggi.

Tabel 3. Rerata momen kappa (k)

uji praktikalitas (field test) guru.

\begin{tabular}{c|c|c} 
No & Aspek yang Dinilai & $\mathbf{k}$ \\
\hline 1 & Kemudahan penggunaan & 0,86 \\
\hline 2 & Efisiensi waktu pembelajaran & 0,75 \\
\hline 3 & Manfaat & 0,79 \\
\hline \multicolumn{2}{c}{ Rerata momen kappa } & $\mathbf{0 , 8 0}$
\end{tabular}

Tabel 4. Rerata momen kappa (k)

uji praktikalitas (field test) siswa.

\begin{tabular}{c|c|c} 
No & Aspek yang Dinilai & $\mathbf{k}$ \\
\hline 1 & Kemudahan penggunaan & 0,76 \\
\hline 2 & Efisiensi waktu pembelajaran & 0,59 \\
\hline 3 & Manfaat & 0,75 \\
\hline & Rerata momen kappa & $\mathbf{0 , 7 0}$
\end{tabular}

\subsection{Diskusi}

\subsubsection{Proses pengembangan modul reaksi oksidasi reduksi berbasis inkuiri terbimbing}

Modul dikembangkan untuk aktivitas kelas dan laboratorium. Hal ini disesuaikan dengan kompetensi dasar (KD) materi reaksi oksidasi reduksi yaitu menuntut adanya pemahaman konsep reaksi oksidasi-reduksi oleh peserta didik melalui aktivitas langsung peserta didik di laboratorium. Selain itu, modul yang dikembangkan menggunakan model berupa gambar, tabel, dan bagan yang dipresentasikan pada tiga level representasi kimia (makroskopik, submikroskopik, dan simbolik). Penyampaian konsep kimia pada tiga level representasi kimia secara lengkap dapat membantu peserta didik untuk membentuk konsep yang utuh dan sesuai dengan konsep kimia yang sebenarnya.

\subsubsection{Validitas modul oksidasi reduksi berbasis inkuiri terbimbing}

Hasil analisis lembar validasi kelima validator dengan menggunakan formula kappa cohen menunjukkan modul yang dikembangkan memiliki validitas komponen isi yang tinggi dengan nilai momen kappa sebesar 0,75, komponen konstruksi tinggi dengan momen kappa sebesar 0,75, dan validitas komponen kebahasaan dan grafis yang sangat tinggi dengan momen kappa masing-masing sebesar 0,77 dan 0,83 . Nilai validitas modul pada masing-masing komponen menunjukkan modul memiliki tingkat validitas tinggi dengan momen kappa sebesar 0,77. Berdasarkan nilai validitas tersebut, penulis menyimpulkan bahwa modul yang dikembangkan sudah valid. Bahan ajar yang valid merupakan bahan ajar yang dirancang berdasarkan kurikulum dan rasional teoritik yang kuat serta memiliki konsistensi internal antar komponen bahan ajar ${ }^{[12]}$. Walaupun modul yang dikembangkan sudah valid, namun masih diperlukan beberapa perbaikan terhadap modul berbasis inkuiri terbimbing yang dikembangkan sesuai dengan saran dari masingmasing validator.

\subsubsection{Praktikalitas modul oksidasi reduksi berbasis inkuiri terbimbing}

Hasil penilaian angket respon guru dan pengolahan data menunjukkan modul yang dikembangkan sudah praktis untuk digunakan dalam pembelajaran di sekolah. Nilai momen kappa praktikalitas modul berdasarkan angket respon guru sebesar 0,80 dengan kategori tinggi. Sedangkan momen kappa praktikalitas berdasarkan angket respon peserta didik sebesar 0,70 dengan kategori tinggi.

Guru dan peserta didik menilai bahwa modul berbasis inkuiri terbimbing yang dikembangkan memiliki kepraktisan yang tinggi karena modul yang dikembangkan oleh penulis telah disusun berdasarkan indikator pencapaian kompetensi yang dikembangkan. Modul yang praktis artinya dapat digunakan di lapangan secara berkesinambungan, mudah digunakan sesuai dengan waktu yang dibutuhkan dalam penggunaan, tepat dan menarik sehingga dapat meningkatkan minat peserta didik dalam belajar ${ }^{[13]}$.

Hasil analisis jawaban peserta didik untuk soal HOTS pada tahap aplikasi diperoleh rerata persentase jawaban peserta didik adalah $78,6 \%$. Sementara hasil analisis nilai evaluasi peserta didik adalah 79,8. Hal membuktikan bahwa antara jawaban peserta didik pada modul dan penilaian peserta didik berdasarkan angket respon peserta didik memiliki hubungan yang relevan yaitu berkategori baik dengan nilai di atas KKM $(>75)$. Data ini menunjukkan hasil bahwa penggunaan modul yang dikembangkan dapat memudahkan atau menuntun peserta didik untuk menemukan konsep, memahami konsep, dan mengaplikasikan konsep dalam bentuk soal latihan.

Hasil analisis kemampuan berpikir tingkat tinggi peserta didik pada soal evaluasi diperoleh rerata keberhasilan peserta didik dalam menjawab soal HOTS pada lembar evaluasiadalah 69,6\%. Hal ini menunjukkan bahwa modul reaksi oksidasi reduksi berbasis inkuiri terbimbing mampu mengukur kemampuan berpikir tingkat tinggi peserta didik dimana lebih dari 50\% peserta didik yang diambil sebagai sampel penelitian mampu menjawab soal tipe HOTS.

\section{SIMPULAN}

Berdasarkan penelitian yang telah dilakukan dapat disimpulkan bahwa modul berbasis inkuiri terbimbing yang dihasilkan memiliki kategori kevalidan yang tinggi dengan momen kappa sebesar 0,77 dan nilai momen kappa praktikalitas modul berdasarkan angket respon praktikalitas guru sebesar 0,80 dengan kategori sangat tinggi. Sedangkan momen kappa praktikalitas berdasarkan angket respon praktikalitas peserta didik sebesar 0,70 dengan kategori tinggi. 


\section{REFERENSI}

1. RI P. Perubahan Atas Peraturan Menteri Pendidikan Dan Kebudayaan Nomor 59

Tahun 2014 Tentang Kurikulum 2013 Sekolah Menengah Atas/Madrasah Aliyah. 2018.

2. Medina P. Analisis Miskonsepsi Siswa Kelas X pada Materi Larutan Elektrolit dan Non-elektrolit Serta Reaksi Oksidasi dan Reduksi dalam Pembelajaran Kimia di SMA Kota Padang. I Pendidik dan Teknol Inf 2015;2(1):1-9.

3. Jannah RR, Utami L. Identifikasi Miskonsepsi Siswa pada Materi Reaksi Redoks Menggunakan Certainty of Respons Indexs. I Indones Soc Integr Chem 2018;10(2):1-11.

4. Salam AGI, Fajaroh F, Effandiy D.

Pengembangan Bahan Ajar Reaksi Oksidasi Reduksi berbasis Inkuiri Terbimbing untuk SMA/Ma Kelas X. Pendi IPA Pasca Sarj UM 2017;2(1):349-57.

5. Departemen Pendidikan Nasional. Panduan Pengembangan Bahan Ajar. Jakarta:

Departemen Pendidikan Nasional, Direktorat Lenderal Manajemen Pendidikan Dasar dan Menengah, Direktorat Pembinaan Sekolah Menengah Atas; 2008.

6. Matthew B., Kenneth I. A Study On The Effects Of Guided Inquiry Teaching Method On Students Achievement In Logic. J Int Res 2013;1(2):135-9.

7. Hanson DM. Designing Process-Oriented Guided-Inquiry Activities. Pacific Crest 2005;(2nd edition).

8. Marhadi H, Erlisnawati E. Peningkatan Kemampuan Berpikir Tingkat Tinggi/Higher Order Thinking Skill (HOTS) Mahasiswa PGSD FKIP UR. Pedagog I Pendidik Guru Sekol Dasar 2018;6(1).

9. Kemendikbud. Modul Penyusunan Soal Higher Order Thinking Skills (HOTS). Jakarta: Direktorat Pembinaan SMA; 2017.

10. Perifta SE, Iryani. Uji Validitas Modul Hukum Dasar Kimia dan Stoikiometri Berbasis Inkuiri Terbimbing. Edukimia 2018;1(3):1-8.

11. Plomp T. Educational Design Research: An Introduction", dalam An Introduction to Educational Research. Enschede, Netherland: National Institute for Curriculum Development; 2007.

12. Boslaugh S dan PAW. Statistics in a Nutshell, a desktop quick reference. Beijing, Cambridge, Famham, Köln, Sebastopol, Taipei,Tokyo: O'reilly;

13. Sukardi. Evaluasi Pendidikan: Prinsip \& Operasionalnya. Jakarta: Bumi Aksara; 2012. 